\title{
Efficacy of selected fungicides against mycelial growth of Colletotrichum spp. causing anthracnose of chilli
}

\section{Nuraini $\mathrm{MN}^{1}$ and Latiffah $\mathrm{Z}^{2 *}$}

\author{
${ }^{1}$ Faculty of Plantation and Agrotechnology, Universiti Teknologi MARA, Jasin Campus, 77300, Merlimau, Melaka, \\ Malaysia \\ ${ }^{2 *}$ School of Biological Sciences, Universiti Sains Malaysia, 11800 USM, Penang, Malaysia
}

\begin{abstract}
Nuraini MN, Latiffah Z 2019 - Efficacy of selected fungicides against mycelial growth of Colletotrichum spp. causing anthracnose of chilli. Plant Pathology \& Quarantine 9(1), 43-51, Doi $10.5943 / \mathrm{ppq} / 9 / 1 / 5$
\end{abstract}

\begin{abstract}
Many Colletotrichum spp. are associated with chilli anthracnose, and fungicides remain one of the important means to manage the disease. The present study evaluated the effectiveness of two contact fungicides, mancozeb and propineb, and two systemic fungicides, benomyl and difenoconazole to inhibit mycelial growth of seven Colletotrichum spp. causing chilli anthracnose using poison food and agar disc diffusion assays. In vitro tests of the fungicides showed that the two systemic fungicides effectively inhibited mycelial growth of $C$. fructicola, $C$. siamense, $C$. truncatum, $C$. scovillei, and $C$. fioriniae. The study provides preliminary information on the types of fungicide that are suitable for managing anthracnose of chilli fruits in Malaysia.
\end{abstract}

Key words - Capsicum sp. - chilli - Colletotrichum spp. - contact fungicides - systemic fungicides

\section{Introduction}

Chilli peppers are commonly consumed raw or as an ingredient in local dishes in Malaysia. Anthracnose is one of the most common post-harvest diseases of chilli. Five species of Colletotrichum, $C$. scovillei, C. truncatum, $C$. siamense, $C$. fructicola, and $C$. fioriniae have been identified as the causal pathogens of chilli anthracnose in Peninsular Malaysia (Nuraini \& Latiffah 2018).

Chemical control using fungicides is part of integrated plant disease management to control Colletotrichum spp. infection in chilli. Both contact and systemic fungicides have been applied to reduce the incidence and severity of anthracnose disease (Harp et al. 2008, Ali et al. 2016).

Contact or non-systemic fungicides suppress or inhibit fungal growth to prevent penetration into plant tissues (Elliott et al. 2015). These fungicides are not absorbed by the plant and remain on the plant surface. Therefore, application of contact fungicides after disease development is impractical and inefficient. Systemic fungicides are absorbed by the plant and are considered to be the most effective fungicides as they can be used to restrict fungal infection after the disease is established (Majeed et al. 2014). They can also be applied as protectants or eradicants.

In vitro study of fungicides is important for preliminary screening of fungicides that are effective for controlling anthracnose caused by Colletotrichum species. Choosing the right fungicide is important to maximize effectiveness of the product and to prevent fungicide resistance, 
which is a major constraint in fungicide application. The objective of this study was, therefore, to evaluate the in vitro effectiveness of contact fungicides (mancozeb and propineb) and systemic fungicides (benomyl and difenoconazole) to control mycelial growth of Colletotrichum spp. causing chilli anthracnose.

\section{Materials \& Methods}

\section{Fungal isolates and in vitro fungicide testing}

Forty isolates of Colletotrichum spp., comprising two species of the C. gloeosporiodes species complex (two isolates of $C$. fructicola and five isolates of $C$. siamense), two species of the C. acutatum species complex (four isolates of $C$. fioriniae and 14 isolates of $C$. scovillei), and 15 isolates of $C$. truncatum were used for fungicide testing. The isolates were chosen based on their degree of virulence observed in pathogenicity tests (Nuraini \& Latiffah 2018).

The effects of two contact fungicides, mancozeb and propineb, and two systemic fungicides, benomyl and difenoconazole (Table 1) on mycelial growth of the Colletotrichum isolates were evaluated in vitro, using poison food and agar disc diffusion assay methods. These fungicides have been reported to be effective to inhibit mycelia growth of Colletotrichum spp. causing chilli anthracnose (Peres et al. 2004, Jagtap et al. 2013). Benomyl and difenoconazole were tested at 2 ppm, 4 ppm, 8 ppm, and 10 ppm according to the concentrations reported by Gopinath et al. (2006). Mancozeb and propineb were tested at $100 \mathrm{ppm}, 200 \mathrm{ppm}, 400 \mathrm{ppm}$ and $500 \mathrm{ppm}$ based on concentrations reported by Rajesha et al. (2010).

Table 1 Fungicides tested to control mycelial growth of Colletotrichum spp. causing chilli anthracnose.

\begin{tabular}{lllll}
\hline $\begin{array}{l}\text { Active } \\
\text { ingredient }\end{array}$ & $\begin{array}{l}\text { Trade/ } \\
\text { product name }\end{array}$ & Fungicide group & Form & Type \\
\hline Benomyl & Benlate & Benzimidazoles & Wettable powder & Systemic \\
Difenoconazole & Score 250 EC & Triazole & Emulsifiable concentrate & Systemic \\
Mancozeb & Dithane & Dithiocarbamates & Wettable powder & Contact \\
Propineb & Antracol & Dithiocarbamates & Wettable powder & Contact \\
\hline
\end{tabular}

\section{Analysis of mycelial growth by poison food assay}

For the poison food assay, potato dextrose agar (PDA) plates containing fungicide solution at the desired concentrations $(1 \mathrm{ppm}=1 \mu \mathrm{g} / \mathrm{ml})$ were used. The concentrations were obtained by adding appropriate amounts of stock solution of fungicides to PDA plates. A $5 \mathrm{~mm}$ diam. mycelial plug obtained from 7-day-old culture of Colletotrichum isolates was placed in the centre of each plate. As a control, Colletotrichum isolates were cultured on PDA plates without fungicide. All the treatments were in three replicates and repeated twice. The plates were incubated at $27 \pm 1^{\circ} \mathrm{C}$. After 7 days, colony diameters were measured in two perpendicular directions. The percentage of mycelial growth inhibition versus the control was calculated using the following formula (Grover \& Moore 1962):

$$
\begin{aligned}
& \text { Inhibition of mycelial } \\
& \text { growth (\%) }
\end{aligned}=\frac{\text { Mycelial growth (control) - mycelial growth (treatment) }}{\text { Mycelial growth (control) }}
$$

\section{Analysis of mycelial growth by agar disc diffusion assay}

Prior to fungicide treatments, sterile PDA plates were inoculated with $1 \mathrm{ml}$ of conidial suspension $\left(10^{6}\right.$ conidia/ml) of 7-day-old cultures of the Colletotrichum isolates. Then, $6 \mathrm{~mm}$ diam. sterile filter paper discs (Whatman no. 1) were soaked in the fungicide solutions of different 
concentrations. As a control, discs were soaked in sterile distilled water. The treatment and control discs were then placed onto the inoculated PDA plates and incubated at $27 \pm 1^{\circ} \mathrm{C}$ for $48 \mathrm{~h}$. The diameter of the inhibition zone was measured and recorded. All the treatments were repeated twice.

\section{Statistical analysis}

Differences between treatment groups and controls were analysed using analysis of variance (ANOVA) with Turkey's pairwise comparisons using MINITAB® statistical software version 17. A $p$-value $<0.05$ was considered significant.

\section{Results}

\section{Effects of fungicides on mycelial growth of $\boldsymbol{C}$. gloeosporiodes species complex}

In both poison food and agar diffusion assays, benomyl and difenoconazole effectively inhibited the mycelial growth of $C$. fructicola and $C$. siamense (Tables 2, 3). For $C$. fructicola and C. siamense, benomyl caused $100 \%$ mycelial growth inhibition at all concentrations tested $(2,4,8$, and $10 \mathrm{ppm}$ ). Generally, with increasing fungicide concentration, the percentage of inhibition of mycelial growth of all isolates increased, and all inhibitory effects were significant at $p<0.05$. In the agar disc diffusion assay, mean inhibition zones were $1.28-5.15 \mathrm{~cm}$ (Table 3 ). In both assays, mancozeb and propineb were not effective in inhibiting the mycelial growth of $C$. fructicola and $C$. siamense (Tables 2, 3).

\section{Effects of fungicides on mycelial growth of $C$. truncatum}

Difenoconazole effectively inhibited mycelial growth of $C$. truncatum using poison food assay (Table 2). Mycelial growth inhibition by the tested fungicides increased with increasing concentration. At $10 \mathrm{ppm}$, difenoconazole inhibited mycelial growth by $74.1 \%$, which was the strongest effect observed. The lowest effect was observed for benomyl, with $3.6 \%$ at $4 \mathrm{ppm}$, and only five out of 15 isolates showed mycelial growth inhibition at this concentration (Table 2). Propineb did not inhibit mycelial growth of $C$. truncatum at all concentrations tested.

The mean inhibition zones for all tested isolates of $C$. truncatum are presented in Table 3. The inhibition zones for all isolates treated with the four fungicides at different concentrations were significantly different at $p<0.05$. Difenoconazole at $10 \mathrm{ppm}$ had the strongest effect, with a mean zone of inhibition of $2.84 \mathrm{~cm}$, followed by mancozeb at $500 \mathrm{ppm}$ with a mean inhibition zone of $2.23 \mathrm{~cm}$.

\section{Effects of fungicides on mycelial growth of $C$. acutatum species complex}

Benomyl and difenoconazole were the most effective in inhibiting mycelial growth of $C$. scovillei and C. fioriniae at all concentrations tested (Tables 2, 3). Mancozeb and propineb were only effective at higher concentrations (400 and $500 \mathrm{ppm}$ ).

At all concentrations tested, difenoconazole inhibited mycelial growth of $C$. fioriniae by 64.7-78.1\% and benomyl inhibited mycelial growth by 76.1-89.1\%. Mancozeb and propineb were less effective, with inhibition by $41.2 \%$ and $32.8 \%$, respectively, at $500 \mathrm{ppm}$ (Table 2). The largest mean inhibition zones of $C$. fioriniae were observed under exposure to benomyl and difenoconazole; at $10 \mathrm{ppm}$, benomyl and difenoconazole treatments resulted in mean inhibition zones of $4.65 \mathrm{~cm}$ and $4.05 \mathrm{~cm}$, respectively (Table 3). Propineb did not inhibit mycelial growth of C. fioriniae even at $500 \mathrm{ppm}$, which was the highest concentration tested.

Similar results were observed for $C$. scovillei. Difenoconazole was the most effective fungicide. It inhibited the mycelial growth of $C$. scovillei by $71.7-87.0 \%$ at all concentrations tested, followed by benomyl, with 59.6-78.2\% inhibition. At $500 \mathrm{ppm}$, mancozeb and propineb exposure resulted in $48.8 \%$ and $38.2 \%$ mycelial growth inhibition, respectively (Table 2). For $C$. scoville $i$, the highest mean inhibition zones were recorded for benomyl and difenoconazole, the 
lowest for mancozeb and propineb. At $10 \mathrm{ppm}$, benomyl and difenoconazole induced mean inhibition zones of $4.36 \mathrm{~cm}$ and $3.75 \mathrm{~cm}$, respectively. At $500 \mathrm{ppm}$, the mean of inhibition zone under mancozeb exposure was $2.08 \mathrm{~cm}$, while propineb did not inhibit the mycelial growth of $C$. scovillei at all concentrations tested (Table 3 ).

Table 2 Percentage inhibition of mycelial growth of Colletotrichum spp. exposed to four fungicides at different concentrations using poison food assay.

\begin{tabular}{|c|c|c|c|c|c|}
\hline \multirow[t]{2}{*}{ Species } & \multirow[t]{2}{*}{ Fungicide } & \multicolumn{4}{|c|}{ Inhibition of mycelial growth (\%) } \\
\hline & & 2 ppm*/100ppm** & 4 ppm*/200ppm** & 8 ppm*/400ppm** & 10 ppm*/500ppm** \\
\hline \multirow[t]{5}{*}{ C. fructicola } & Benomyl & $100.00^{\mathrm{a}}$ & $100.00^{\mathrm{a}}$ & $100.00^{\mathrm{a}}$ & $100.00^{\mathrm{a}}$ \\
\hline & Difenoconazole & $60.33^{\mathrm{cd}}$ & $61.98^{\mathrm{c}}$ & $68.83^{\mathrm{c}}$ & $71.41^{\mathrm{c}}$ \\
\hline & Mancozeb & $22.04^{\mathrm{f}}$ & $25.80^{\mathrm{e}}$ & $29.78^{\mathrm{ef}}$ & $34.07^{\mathrm{ef}}$ \\
\hline & Propineb & $20.09^{f}$ & $25.27^{\mathrm{e}}$ & $27.34^{\mathrm{ef}}$ & $28.77^{\mathrm{f}}$ \\
\hline & Control & $0.00^{\mathrm{h}}$ & $0.00^{\mathrm{g}}$ & $0.00^{\mathrm{h}}$ & $0.00^{\mathrm{h}}$ \\
\hline \multirow[t]{5}{*}{ C. siamense } & Benomyl & $100.00^{\mathrm{a}}$ & $100.00^{\mathrm{a}}$ & $100.00^{\mathrm{a}}$ & $100.00^{\mathrm{a}}$ \\
\hline & Difenoconazole & $63.99^{\mathrm{cd}}$ & $67.16^{\mathrm{c}}$ & $72.05^{\mathrm{c}}$ & $78.60^{\mathrm{bc}}$ \\
\hline & Mancozeb & $26.82^{f}$ & $30.05^{\mathrm{e}}$ & $32.72^{\text {ef }}$ & $36.04^{\mathrm{ef}}$ \\
\hline & Propineb & $22.80^{\mathrm{f}}$ & $26.22^{\mathrm{e}}$ & $29.53^{\mathrm{f}}$ & $31.73^{\mathrm{f}}$ \\
\hline & Control & $0.00^{\mathrm{h}}$ & $0.00^{\mathrm{g}}$ & $0.00^{\mathrm{h}}$ & $0.00^{\mathrm{h}}$ \\
\hline \multirow[t]{5}{*}{ C. truncatum } & Benomyl & $2.67^{\mathrm{g}}$ & $3.57^{\mathrm{f}}$ & $3.84^{\mathrm{g}}$ & $4.66^{\mathrm{g}}$ \\
\hline & Difenoconazole & $55.55^{\mathrm{d}}$ & $62.37^{\mathrm{c}}$ & $67.83^{\mathrm{c}}$ & $74.1^{\mathrm{c}}$ \\
\hline & Mancozeb & $30.95^{\mathrm{f}}$ & $34.84^{\mathrm{e}}$ & $38.90^{\mathrm{e}}$ & $43.12^{\text {de }}$ \\
\hline & Propineb & $31.80^{\mathrm{ef}}$ & $33.83^{\mathrm{e}}$ & $37.24^{\mathrm{ef}}$ & $38.97^{\mathrm{ef}}$ \\
\hline & Control & $0.00^{\mathrm{h}}$ & $0.00^{\mathrm{g}}$ & $0.00^{\mathrm{h}}$ & $0.00^{\mathrm{h}}$ \\
\hline \multirow[t]{5}{*}{ C. scovillei } & Benomyl & $59.64^{\mathrm{d}}$ & $64.93^{c}$ & $70.55^{\mathrm{c}}$ & $78.19^{c}$ \\
\hline & Difenoconazole & $71.66^{\mathrm{bc}}$ & $77.67^{\mathrm{b}}$ & $82.94^{b}$ & $87.04^{\mathrm{b}}$ \\
\hline & Mancozeb & $38.05^{\mathrm{e}}$ & $41.39^{d}$ & $45.86^{d}$ & $48.85^{\mathrm{d}}$ \\
\hline & Propineb & $28.41^{\mathrm{f}}$ & $32.33^{\mathrm{e}}$ & $34.59^{\mathrm{ef}}$ & $38.18^{\mathrm{ef}}$ \\
\hline & Control & $0.00^{\mathrm{h}}$ & $0.00^{\mathrm{g}}$ & $0.00^{\mathrm{h}}$ & $0.00^{\mathrm{h}}$ \\
\hline \multirow[t]{5}{*}{ C. fioriniae } & Benomyl & $76.19^{\mathrm{b}}$ & $79.30^{\mathrm{b}}$ & $84.87^{\mathrm{b}}$ & $89.09^{\mathrm{ab}}$ \\
\hline & Difenoconazole & $64.69^{\mathrm{bcd}}$ & $68.73^{\mathrm{bc}}$ & $72.81^{\mathrm{c}}$ & $78.28^{\mathrm{bc}}$ \\
\hline & Mancozeb & $29.61^{\mathrm{ef}}$ & $39.42^{\text {de }}$ & $37.19^{\text {def }}$ & $41.19^{\text {def }}$ \\
\hline & Propineb & $22.90^{\mathrm{f}}$ & $25.10^{\mathrm{e}}$ & $29.08^{f}$ & $32.79^{f}$ \\
\hline & Control & $0.00^{\mathrm{h}}$ & $0.00^{\mathrm{g}}$ & $0.00^{\mathrm{h}}$ & $0.00^{\mathrm{h}}$ \\
\hline
\end{tabular}

- Means followed by the same letter are not significantly different $(\mathrm{p}<0.05)$ according to Turkey's test. 
*Benomyl and difenoconazole tested at 2 ppm, 4 ppm, 8 ppm and $10 \mathrm{ppm}$.

**Mancozeb and propineb tested at $100 \mathrm{ppm}, 200 \mathrm{ppm}, 400 \mathrm{ppm}$ and $500 \mathrm{ppm}$.

Table 3 Mean zone of inhibition of Colletotrichum spp. treated with four fungicides at different concentrations using agar diffusion assay.

\begin{tabular}{|c|c|c|c|c|c|}
\hline \multirow[t]{2}{*}{ Species } & \multirow[t]{2}{*}{ Fungicide } & \multicolumn{4}{|c|}{ Mean zone of inhibition $(\mathrm{cm})$} \\
\hline & & 2ppm*/100ppm** & 4ppm*/200ppm** & 8ppm*/400ppm** & 10ppm*/500ppm** \\
\hline \multirow[t]{5}{*}{ C. fructicola } & Benomyl & $3.73^{\mathrm{ab}}$ & $4.38^{\mathrm{ab}}$ & $4.95^{\mathrm{a}}$ & $5.10^{\mathrm{a}}$ \\
\hline & Difenoconazole & $2.40^{\text {cdefg }}$ & $2.83^{\mathrm{de}}$ & $3.45^{\mathrm{bc}}$ & $3.75^{\mathrm{cd}}$ \\
\hline & Mancozeb & $1.28^{\mathrm{fgh}}$ & $1.48^{\mathrm{fg}}$ & $1.73^{\mathrm{de}}$ & $2.40^{\mathrm{ef}}$ \\
\hline & Propineb & $0.00^{\mathrm{i}}$ & $0.00^{\mathrm{h}}$ & $0.00^{f}$ & $0.00^{\mathrm{g}}$ \\
\hline & Control & $0.00^{\mathrm{i}}$ & $0.00^{\mathrm{h}}$ & $0.00^{\mathrm{f}}$ & $0.00^{\mathrm{g}}$ \\
\hline \multirow{5}{*}{ C. siamense } & Benomyl & $4.17^{\mathrm{a}}$ & $4.51^{\mathrm{a}}$ & $4.93^{\mathrm{a}}$ & $5.15^{\mathrm{a}}$ \\
\hline & Difenoconazole & $2.38^{\mathrm{de}}$ & $2.97^{\mathrm{d}}$ & $3.34^{\mathrm{c}}$ & $3.85^{\mathrm{d}}$ \\
\hline & Mancozeb & $1.52^{\mathrm{gh}}$ & $1.84^{\mathrm{fg}}$ & $2.06^{\mathrm{de}}$ & $2.49^{\mathrm{ef}}$ \\
\hline & Propineb & $0.00^{\mathrm{i}}$ & $0.00^{\mathrm{h}}$ & $0.00^{\mathrm{f}}$ & $0.00^{\mathrm{g}}$ \\
\hline & Control & $0.00^{\mathrm{i}}$ & $0.00^{\mathrm{h}}$ & $0.00^{\mathrm{f}}$ & $0.00^{\mathrm{g}}$ \\
\hline \multirow[t]{5}{*}{ C. truncatum } & Benomyl & $0.00^{\mathrm{i}}$ & $0.00^{\mathrm{h}}$ & $0.00^{f}$ & $0.00^{\mathrm{g}}$ \\
\hline & Difenoconazole & $1.46^{\mathrm{h}}$ & $1.93^{\mathrm{f}}$ & $2.37^{\mathrm{d}}$ & $2.84^{\mathrm{e}}$ \\
\hline & Mancozeb & $1.43^{\mathrm{h}}$ & $1.71^{\mathrm{fg}}$ & $2.00^{\mathrm{e}}$ & $2.23^{\mathrm{f}}$ \\
\hline & Propineb & $0.00^{\mathrm{i}}$ & $0.00^{\mathrm{h}}$ & $0.00^{\mathrm{f}}$ & $0.00^{\mathrm{g}}$ \\
\hline & Control & $0.00^{\mathrm{i}}$ & $0.00^{\mathrm{h}}$ & $0.00^{\mathrm{f}}$ & $0.00^{\mathrm{g}}$ \\
\hline \multirow[t]{5}{*}{ C. scovillei } & Benomyl & $3.08^{\mathrm{bc}}$ & $3.65^{b c}$ & $4.00^{\mathrm{b}}$ & $4.36^{\mathrm{bc}}$ \\
\hline & Difenoconazole & $2.54^{\mathrm{d}}$ & $2.98^{\mathrm{d}}$ & $3.36^{\mathrm{c}}$ & $3.75^{\mathrm{d}}$ \\
\hline & Mancozeb & $1.23^{\mathrm{h}}$ & $1.49^{\mathrm{g}}$ & $1.79^{\mathrm{e}}$ & $2.08^{\mathrm{f}}$ \\
\hline & Propineb & $0.00^{\mathrm{i}}$ & $0.00^{\mathrm{h}}$ & $0.00^{\mathrm{f}}$ & $0.00^{\mathrm{g}}$ \\
\hline & Control & $0.00^{\mathrm{i}}$ & $0.00^{\mathrm{h}}$ & $0.00^{\mathrm{f}}$ & $0.00^{\mathrm{g}}$ \\
\hline \multirow[t]{5}{*}{ C. fioriniae } & Benomyl & $3.31^{\mathrm{bc}}$ & $3.85^{\mathrm{abc}}$ & $4.16^{\mathrm{b}}$ & $4.65^{\mathrm{ab}}$ \\
\hline & Difenoconazole & $2.84^{\text {bcd }}$ & $3.16^{\mathrm{cd}}$ & $3.70^{\mathrm{bc}}$ & $4.05^{\mathrm{bcd}}$ \\
\hline & Mancozeb & $1.84^{\text {efgh }}$ & $1.98^{\mathrm{efg}}$ & $2.10^{\mathrm{de}}$ & $2.33^{\mathrm{ef}}$ \\
\hline & Propineb & $0.00^{\mathrm{i}}$ & $0.00^{\mathrm{h}}$ & $0.00^{f}$ & $0.00^{\mathrm{g}}$ \\
\hline & Control & $0.00^{\mathrm{i}}$ & $0.00^{\mathrm{h}}$ & $0.00^{\mathrm{f}}$ & $0.00^{\mathrm{g}}$ \\
\hline
\end{tabular}

- Mean \pm standard deviation followed by the same letter are not significantly different $(\mathrm{p}<0.05)$ according to Turkey's test.

*Benomyl and difenoconazole tested at 2 ppm, 4 ppm, 8 ppm and 10 ppm.

**Mancozeb and propineb tested at 100 ppm, 200 ppm, 400 ppm and 500 ppm. 


\section{Discussion}

In vitro fungicide testing is important for preliminary screening and evaluation of the effectiveness of fungicides to control a specific fungal pathogen. Laboratory evaluation allows researchers to distinguish effective from ineffective fungicides and, thus, select appropriate candidate fungicides for field tests. In vitro fungicide testing is also important to determine the minimum or effective dose required to control the fungus, as well as to detect fungicide resistance. In-vitro tests have been widely implemented in previous studies to determine the efficacy of fungicides towards Colletotrichum spp. causing anthracnose on various types of crops, e.g., $C$. truncatum on chilli (Gopinath et al. 2006), C. gloeosporioides on mango (Kumar et al. 2007), and C. acutatum on tomato (Chapin et al. 2006).

The present study indicated that benomyl effectively inhibited mycelial growth of $C$. fructicola and $C$. siamense, even at the lowest concentration (2 ppm). Similar results were obtained by Velho et al. (2015) who reported that the mycelial growth of $C$. fructicola isolates causing apple anthracnose was completely inhibited by treatment with benomyl at 0.5 and $10 \mathrm{ppm}$. Growth of $C$. gloeosporioides causing chilli (Rampersad \& Teelucksingh 2012) and mango (Martínez et al. 2009) anthracnose was strongly inhibited by benomyl. The mycelial growth of $C$. gloeosporioides causing citrus anthracnose was also highly inhibited by benomyl at 0.1-10 ppm (Aiello et al. 2015).

The second most effective fungicide inhibiting mycelial growth of $C$. fructicola and $C$. siamense was difenoconazole. Lima et al. (2015) reported that difenoconazole at $0.5 \mathrm{ppm}$ inhibited by $60 \%$ mycelial growth of $C$. fructicola causing anthracnose of mango. In a study by Patil et al. (2010), difenoconazole completely inhibited the mycelial growth of $C$. gloeosporioides causing leaf blight of sapota fruit (chikoo). Mancozeb and propineb had very limited inhibitory effects on mycelial growth of $C$. fructicola and $C$. siamense, even at 500 ppm (Table 2). Kumar et al. (2007) examined the efficacy of different fungicides against $C$. gloeosporioides from mango and found that mancozeb was ineffective in inhibiting the mycelial growth $(<40 \%$ inhibition). In a study by Jayalakshmi et al. (2012) propineb was ineffective in inhibiting mycelial growth of $C$. gloeosporioides causing anthracnose of pomegranate, with only $14.83 \%$ inhibition at $100 \mathrm{ppm}$. In contrast, Lim et al. (2009) reported that propineb at a very high concentration (1500 ppm) effectively inhibited mycelial growth of $C$. gloeosporioides causing persimmon anthracnose by $90 \%$.

For $C$. truncatum isolates, only difenoconazole exhibited strong mycelial growth inhibition of $82.14 \%$ at $10 \mathrm{ppm}$. Gopinath et al. (2006) reported that difenoconazole strongly inhibited mycelial growth of $C$. truncatum causing chilli anthracnose at $10 \mathrm{ppm}(79.44 \%)$ and $25 \mathrm{ppm}(90 \%)$. Gawade et al. (2009) screened five fungicides for their efficacy against $C$. truncatum and found that difenoconazole was among the most effective, with $82.91 \%$ inhibition at $100 \mathrm{ppm}$. Mancozeb and propineb showed low effectiveness ( $<50 \%$ inhibition), even at $500 \mathrm{ppm}$, for all $C$. truncatum isolates tested. Similar results were reported by Alam \& Basu (2014); mancozeb and propineb were not very effective in inhibiting mycelial growth of $C$. truncatum, with $38 \%$ and $26.8 \%$ inhibition at $250 \mathrm{ppm}$, respectively. In another study using in vitro testing of mancozeb against $C$. truncatum, this fungicide was not effective at $500 \mathrm{ppm}$, with only $42.96 \%$ mycelial growth inhibition, but it was effective at $1500 \mathrm{ppm}$, with 75\% mycelial growth inhibition (Jagtap et al. 2013). Benomyl was not effective against $C$. truncatum; mycelial growth was inhibited in only five isolates by $10 \mathrm{ppm}$ of benomyl. Similarly, Rampersad \& Teelucksingh (2012) reported that benomyl was not effective in inhibiting the mycelial growth of $C$. truncatum causing chilli anthracnose at concentration less than $10 \mathrm{ppm}$ (16.2\% mycelial inhibition), but was effective at concentrations of more than $100 \mathrm{ppm}$ (63\% mycelial inhibition). However, Ramdial \& Rampersad (2015) showed that benomyl completely inhibited mycelial growth of all $C$. truncatum isolates causing anthracnose of bell pepper at $0.1,1$, and $10 \mathrm{ppm}$.

The fungicide efficacies for the $C$. scovillei and $C$. fioriniae isolates tested were quite similar to previous results reported for C. acutatum sensu lato (Freeman 2008). In this study, benomyl and difenoconazole at $10 \mathrm{ppm}$ inhibited mycelial growth by more than $60 \%$ for all isolates of $C$. scovillei and C. fioriniae tested. Peres et al. (2004) reported that mycelial growth of C. acutatum 
causing citrus anthracnose was effectively inhibited by benomyl at $1 \mathrm{ppm}$. Difenoconazole is also effective in inhibiting the mycelial growth of $C$. acutatum sensu lato causing strawberry anthracnose at low concentration (0.15 ppm) (Freeman et al. 1997). However, Kenny et al. (2012) showed that benomyl was effective only at the high concentration of $100 \mathrm{ppm}$ for inhibiting growth of C. acutatum.

Mancozeb and propineb were not effective in inhibiting the mycelial growth of $C$. scovillei and $C$. fioriniae. Similar results were reported by Jilkova et al. (2015); among seven fungicides tested, mancozeb was the least effective against $C$. acutatum sensu lato causing anthracnose of lupin and strawberry. In contrast, Kenny et al. (2012) found that mancozeb at 100 ppm was quite effective (71\% growth inhibition) against $C$. acutatum from coffee berry.

In general, all the fungicides tested in this study to some extent inhibited the mycelial growth of Colletotrichum isolates, and their inhibitory effect increased with higher concentration. The two systemic fungicides, benomyl and difenoconazole, were the most effective against all five isolates tested in both poison food and agar disc diffusion assays. Colletotrichum spp. causing postharvest chilli anthracnose can attack all plant parts, including seeds, leaves, roots, and fruits (Saxena et al. 2014). Therefore, systemic fungicides are suitable to control anthracnose infections, as they are taken up via the roots and distributed to the various plant tissues, including the infection sites. The contact fungicides, mancozeb and propineb, were less effective in inhibiting the mycelial growth of Colletotrichum spp. causing chilli anthracnose. As contact fungicides are not absorbed by the plant and are effective only at the site of infection, they are more suitable to control local infections, such as leaf spot disease.

To our knowledge, this is the first report of fungicide efficacy testing of C. fructicola, $C$. siamense, $C$. truncatum, $C$. scovillei, and $C$. fioriniae causing anthracnose of chilli in Malaysia. The results presented provide important information related to the efficacy of systemic and contact fungicides to control chilli anthracnose caused by five species of Colletotrichum. The use of these fungicides should be considered as part of integrated management of chilli anthracnose. In conclusion, this study showed that two systemic fungicides, benomyl and difenoconazole, are effective in inhibiting mycelial growth of $C$. fructicola, $C$. siamense, $C$. truncatum, $C$. scovillei and $C$. fioriniae, while the contact fungicides, mancozeb and propineb were less effective against these five Colletotrichum spp.

\section{Acknowledgements}

This work was supported by a Research University Grant (1001/ PBIOLOGY / 811307) from the Universiti Sains Malaysia, Penang, Malaysia.

\section{References}

Aiello D, Carrieri R, Guarnaccia V, Vitale A et al. 2015 - Characterization and pathogenicity of Colletotrichum gloeosporioides and C. karstii causing preharvest disease on Citrus sinensis in Italy. Journal of Phytopathology 163, 168-177.

Alam MS, Basu A. 2014 - Effect of fungicides on growth of Colletotrichum capsici under in vitro condition. Trends Bioscience 7, 1816-1819.

Ali A, Bordoh PK, Singh A, Siddiqui Y, Droby S. 2016 - Post-harvest development of anthracnose in pepper (Capsicum spp): etiology and management strategies. Crop Protection 90, 132-141.

Chapin LJG, Wang Y, Lutton E, Gardener BBM. 2006 - Distribution and fungicide sensitivity of fungal pathogens causing anthracnose-like lesions on tomatoes grown in Ohio. Plant Disease 90, 397-403.

Elliott M, Shamoun SF, Sumampong G. 2015 - Effects of systemic and contact fungicides on life stages and symptom expression of Phytophthora ramorum in vitro and in planta. Crop Protection 67, 136-144.

Freeman S. 2008 - Management, survival strategies, and host range of Colletotrichum acutatum on strawberry. HortScience 43, 66-68. 
Freeman S, Nizani Y, Dotan S, Even S, Sando T. 1997 - Control of Colletotrichum acutatum in strawberry under laboratory, greenhouse, and field conditions. Plant Disease 81, 749-752.

Gawade DB, Suryawanshi AP, Zagade SN, Wadje AG, Zape AS. 2009 - In vitro evaluation of fungicides, botanicals and bioagents against soybean anthracnose incited by Colletotrichum truncatum. International Journal of Plant Protection 2, 103-107.

Gopinath K, Radhakrishnan NV, Jayaraj J. 2006 - Effect of propiconazole and difenoconazole on the control of anthracnose of chilli fruits caused by Colletotrichum capsici. Crop Protection $25,1024-1031$.

Grover RK, Moore JD. 1962 - Assessment of antifungal property in vitro by poison-food technique. Journal of Phytopathology 52, 876-880.

Harp TL, Pernezny K, Ivey MLL, Miller SA et al 2008 - The etiology of recent pepper anthracnose outbreaks in Florida. Crop Protection 27, 1380-1384.

Jagtap GP, Mali AK, Dey U. 2013 - Bioefficacy of fungicides, bio-control agents and botanicals against leaf spot of turmeric incited by Colletotricum capsici. African Journal of Microbiology Research 7, 1865-1873.

Jayalakshmi K, Nargund VB, Raju J, Benagi VI. 2012 - In vitro management of anthracnose of pomegranate incited by Colletotrichum gloeosporioides (Penz.) Penz. and Sacc. International Journal of Plant Protection 5, 304-307.

Jilkova B, Vichova J, Pokorny R, Vejrazka K. 2015 - Sensitivity of Colletotrichum acutatum isolates to selected fungicides. Acta Universitatis Agriculturae et Silviculturae Mendelianae Brunensis 63, 1111-1119.

Kenny MK, Galea VJ, Price TV. 2012 - Effect of fungicides in vitro and on detached berries on control of coffee berry anthracnose caused by Colletotrichum acutatum and $C$. gloeosporioides. Plant Protection Quarterly 27, 59-63.

Kumar AS, Reddy NE, Reddy KH, Devi MC. 2007 - Evaluation of fungicidal resistance among Colletotrichum gloeosporioides isolates causing mango anthracnose in Agri Export Zone of Andhra Pradesh, India. Plant Pathology Bulletin 16, 157-160.

Lim TH, Choi YH, Lee DW, Han SS, Cha BJ. 2009 - Sensitivity of Colletotrichum gloeosporioides isolated from persimmon to benzimidazoles, mancozeb and propinep. Korean Journal of Pesticide Science 13, 105-110.

Lima NB, Lima WG, Tovar-Pedraza JM, Michereff SJ, Câmara MPS. 2015 - Comparative epidemiology of Colletotrichum species from mango in northeastern Brazil. European Journal of Plant Pathology 41, 679-688.

Majeed A, Ahmad H, Ali MA, Khan H. 2014 - Effect of systemic and contact fungicides on late blight disease and tuber yield of potato. Journal of Agricultural Science and Technology 10, 209-217.

Martínez EP, Hio JC, Osorio JA, Torres MF. 2009 - Identification of Colletotrichum species causing anthracnose on Tahiti lime, tree tomato and mango. Agronomía Colombiana 27, 211218.

Nuraini MN, Latiffah Z. 2018 - Identification and characterization of Colletotrichum spp. associated with chili anthracnose in peninsular Malaysia. European Journal of Plant Pathology 151, 961-973.

Patil PP, Joshi MS, Kadam JJ, Mundhe VG. 2010 - In vitro evaluation of fungicides and bioagents against Colletotrichum gloeosporioides causing leaf blight in sapota. Journal of Plant Disease Sciences 5, 76-78.

Peres NAR, Souza NL, Peever TL, Timmer, LW. 2004 - Benomyl sensitivity of isolates of Colletotrichum acutatum and C. gloeosporioides from citrus. Plant Disease 88, 125-130.

Rajesha G, Mantur SG, Shankar MR, Boranayaka MB, Shadakshari TV. 2010 - In vitro evaluation of fungicides and biocontrol agents against Colletotrichum lindemuthianum causing anthracnose of Dolichos bean. International Journal of Plant Protection 3, 114-116. 
Ramdial H, Rampersad SN. 2015 - Characterization of Colletotrichum spp. causing anthracnose of bell pepper (Capsicum annuum L.) in Trinidad. Phytoparasitica 43, 37-49.

Rampersad SN, Teelucksingh LD. 2012 - Differential responses of Colletotrichum gloeosporioides and $C$. truncatum isolates from different hosts to multiple fungicides based on two assays. Plant Disease 96, 1526-1536.

Saxena A, Raghuwanshi R, Singh HB. 2014 - Molecular, phenotypic and pathogenic variability in Colletotrichum isolates of subtropical region in north-eastern India, causing fruit rot of chillies. Journal of Applied Microbiology 117, 1422-1434.

Velho A, Alaniz S, Casanova L, Mondino P, Stadnik M. 2015 - New insights into the characterization of Colletotrichum species associated with apple diseases in southern Brazil and Uruguay. Fungal Biology 119, 229-244. 